\title{
Spatial distribution of scorpions according to the socioeconomic conditions in Campina Grande, State of Paraíba, Brazil
}

\author{
Thassiany Sarmento Oliveira de Almeida ${ }^{[1],[2]}$, Sayonara Maria Lia Fook ${ }^{[3]}$, \\ Francisco Oscar de Siqueira França ${ }^{[4]}$, Tânia Maria Ribeiro Monteiro ${ }^{[5]}$, \\ Edwirde Luiz Silva ${ }^{[6]}$, Lidiane Cristina Félix Gomes ${ }^{[7]}$ and Aline Maiara Galdino Farias ${ }^{[3]}$
}

\begin{abstract}
[1]. Programa de Pós-Graduação Stricto Sensu em Saúde Coletiva, Universidade Estadual da Paraíba, Campina Grande, Paraíba, Brasil. [2]. Programa de Pós-Graduação Stricto Sensu em Inovação Terapêutica, Universidade Federal de Pernambuco, Recife, Pernambuco, Brasil. [3]. Departamento de Farmácia, Universidade Estadual da Paraíba, Campina Grande, Paraíba, Brasil. [4]. Departamento de Moléstias Infecciosas e Parasitárias, Faculdade de Medicina, Universidade de São Paulo, São Paulo, São Paulo, Brasil. [5]. Departamento de Enfermagem, Universidade Estadual da Paraíba, Campina Grande, Paraíba, Brasil. [6]. Departamento de Estatística, Universidade Estadual da Paraíba, Campina Grande, Paraíba, Brasil. [7]. Instituto Federal da Paraíba, Picuí, Paraíba, Brasil.
\end{abstract}

\begin{abstract}
Introduction: Due to its frequency and morbidity, such as that caused by scorpions have achieved public health importance in certain regions of the world. The present exploratory ecological study aimed to characterize the epidemiological profile and spatial distribution of scorpion stings in Campina Grande, State of Paraíba in Northeastern Brazil. Methods: Geographical information system techniques were used to record the scorpion stings, and Google Earth software, Track Maker, and ArcGIS 10 Esri were used as geocoding databases. The Moran test was used to evaluate spatial correlation, and the Pearson chi-square test was used to analyze associations between scorpion stings and socioeconomic variables. Results: The study evaluated 1,466 scorpion stings. Envenomations were more frequent among women $(\mathrm{n}=908,61.9 \%)$, and most patients were aged 13-28 years $(\mathrm{n}=428,29.2 \%)$. The Southern region of the city had the largest number of registered cases $(\mathrm{n}=548,37.4 \%)$, followed by the Western region $(n=510,34.8 \%)$. Conclusions: Spatial analysis of scorpionism revealed an irregular occurrence in Campina Grande. Further, no association was observed between the socioeconomic factors analyzed and the geographic location of the scorpion envenomations. Detection of spatial areas with an increased risk of scorpionism can help prioritize adoption of preventive measures in these regions to reduce the associated incidence and morbidity.
\end{abstract}

Keywords: Scorpion stings. Tityus envenomation. Scorpionism. Brazil. Spatial analysis.

\section{INTRODUCTION}

Scorpion stings represent an important public health problem in some regions of the world due to their frequency and morbidity. In recent years, Brazil has seen an increase in the reporting of scorpion envenomations and the number of severe scorpionism cases, which can progress to death mainly in children and elderly ${ }^{(1)(2)(3)(4)}$

According to the Sistema de Informação de Agravos de Notificação (SINAN) of the Health Ministry of Brazil, 50,246 scorpion envenomations were registered in 2015 , of which 4,216 were considered severe and and 78 were lethal ${ }^{(5)}$.

Corresponding author: Ms. Thassiany Sarmento Oliveira de Almeida. e-mail: thassysarmento@hotmail.com

Received 10 May 2016

Accepted 8 August 2016
Scorpion venom is a complex blend of low-weight molecules, amino acids and salts, all of which are synthesized in a pair of glands located in the telson ${ }^{(6)}$. The venom acts at specific sites of ion channels like the sodium and potassium channels in the host; in particular, the venom acts on the sodium channels to depolarize the membrane of excitable cells, leading to a wide release of catecholamine and acetylcholine. These neurotransmitters act in several regions of the organism [nerve endings sensory, motor and autonomic nervous system (ANS)] and are responsible for the characteristic signals and symptoms observed in patients ${ }^{(7)(8)}$.

Brazil has approximately 160 scorpion species, but only members of the genus Tityus are responsible for envenomations of medical importance ${ }^{(8)}$. In Brazil, the most relevant species that occur with a high frequency and cause significant morbidity are T. serrulatus, T. bahiensis, T. stigmurus and T. obscurus. T. stigmurusis responsible for most envenomations in the Northeastern region and for some fatal cases registered in Pernambuco ${ }^{(9)(10)}$. 
In the State of Paraíba, 2,992 and 3,591 cases of scorpionism were registered in 2013 and 2014, respectively, of which 6 cases, were considered severe. No deaths occurred in 2013, and two lethal case was noted in $2014^{(11)}$. Importantly, in recent years, there have been a considerable number of scorpion envenomations in the urban areas of Brazil. Majority of the envenomations caused by T. stigmurus occur in urban areas, indicating that the species has adapted to human settlement ${ }^{(9)(12)(13)}$. Spatial analysis of events of scorpion envenomation can help define preferential areas of intervention to prevent envenomations, and consequently, decrease the costs, time, and human resources involved as well as ensure better efficiency in their control and management. Geo-processing allows mapping of living conditions and social inequality. Furthermore, it allows recognition of the frequency and distribution of various determinants in the occurrence of certain health disorders. Although the most affected districts generally have working units of basic health care, health care professionals are not trained to promote information for local populations regarding basic orientations about the prevention of scorpion envenomation and adequate behavior in cases of scorpion sting. Therefore, inter-sector measures may be required to widen public policies related to several illnesses, including envenomation by scorpions $^{(14)(15)}$.

One of the main applications of epidemiologic maps is to facilitate identification of geographic areas and population groups that are exposed to a higher risk of illness or death due to certain illnesses. Such population groups need more attention under preventive programs of health education and promotion. The epidemiology in terms of geographic space provides knowledge about the frequency and distribution of various determinants of the existing territorial heterogeneity and identifies groups sharing similar risk determinants. Further, recognition of exposed groups allows the development of intervention strategies by identification and elimination of specific risk factors ${ }^{(16)}$.

Epidemiologic studies associated with environmental geography about scorpion envenomations and based on a defined population size are relatively rare. Therefore, the present study aimed to evaluate scorpion envenomations that occurred in Campina Grande-PB, Brazil, between 2010 and 2012, by application of geo-processing techniques.

\section{METHODS}

\section{Study design}

The present study was ecological and exploratory in nature. Spatial analysis techniques based on confirmed cases of scorpion stings were used for the entire urban area of Campina GrandePB, Brazil.

\section{Study area}

Campina Grande is located approximately $512 \mathrm{~m}$ above sea level in the hinterland of Paraíba, Northeastern Brazil (Latitude, -7.23072 , longitude, $35.8817,7^{\circ} 13^{\prime} 51^{\prime \prime}$ South, $35^{\circ} 52^{\prime} 54^{\prime \prime}$ West). The territory encompasses an area of approximately $594,182 \mathrm{~km}^{2}$, with a population of 385,213 and a demographic density of 648.31 inhabitants $/ \mathrm{km}^{2}$. It is divided into 6 districts and approximately 50 neighborhoods ${ }^{(17)}$.

\section{Inclusion and exclusion criteria}

Envenomations that occurred between January 2010 and December 2012 in the urban area of Campina Grande were included in the study. However, envenomations registered in rural areas or in other counties and those in which the addresses were incorrect and could not be geo-referred were excluded from this study.

\section{Population and sample}

During the period of the study, 1,806 scorpion envenomations were notified by the notifying center of Centro de Informação e Assistência Toxicológica de Campina Grande (Ceatox-CG). According to the records of the SINAN, places of injuries were identified on the website of the post office and further edited for geo-coding. Of the 1,806 scorpion injuries, 340 were excluded because the addresses of patients were not found. The final sample obtained corresponded to 1,466 geo-processed envenomations with valid addresses.

\section{Incidence of scorpion stings}

In each case, the address of the scorpionism occurrence was taken as an indication of autochthony of its exposition. The incidence rate was determined as the ratio of the noted cases to the estimated population size for the analysis unit. Population size was based on the census of 2010, with the addition of an estimated annual population increase of the community equivalent to $1,15 \%$ for the following years.

\section{Spatial analysis}

The methodological frequency required the use of Google ${ }^{\mathrm{TM}}$ Fusion Tables ${ }^{\mathrm{TM}}$ to perform geo-coding. Furthermore, Google Earth Google Inc application was used to manually locate the cases. Trackmaker Software was used for conversion of data from the Keyhole Markup Language (KML) to the Shapefile format (SHP). The latter format was chosen to manage data in ArcGIS 10 Software from Esri, which, along with the statistical program R 3.1.1. (version for Windows), was used for spatial statistical analysis.

Two maps were generated for the analysis: The first one was for the spatial distribution of scorpion stings and the second one was for kernel density, which consisted of areas with the highest case concentration in a defined region. The statistic program $\mathrm{R}$ (version 3.1.1) was also used for performing Pearson's chisquare test. In order to view the most frequently notified areas, maps and thematic charts were built for the total study period. Thereafter, the spatial autocorrelation Index of Moran was calculated, indicating the existence of self-correlation, based on the distance or geographic continuity between two cases. In the surface unit, the $\mathrm{w}_{\mathrm{ij}}$ was used to measure the continuity between the neighborhoods $i$ and $j$, which is 0 when there is no spatial continuity and 1 when there is continuity. Values $>0$ are considered to have a positive self-correlation, whereas values $=0$ indicate absence of self-correlation. The expected value for the Moran Index is generally very close to $0^{(18)}$. The significance level for all statistical analysis was set at 0.05 . 


\section{Ethical considerations}

The project was approved by the Ethic and Research Committee of State University of Paraíba (number: 20400913.3.0000.5187; resolution number 466/2012 of Conselho Nacional de Saúde/Ministério da Saúde).

\section{RESULTS}

Data from 1,466 scorpion injuries registered between 2010 and 2012, which were assisted by Ceatox-CG, were included in this study. All cases occurred in the urban area of Campina Grande, with an average incidence of 14.1, 11.69, and 11.67 envenomations/10,000 inhabitants in 2010, 2011, and 2012, respectively. The accumulated incidence rate was 37.46 injuries/10,000 inhabitants in the study period of 3 years.

With respect to gender, women were victims of scorpion injuries in $61.9 \%(\mathrm{n}=908)$ of all cases (Table 1). A higher prevalence was observed among individuals aged 13-28 years $(29.2 \%, \mathrm{p}<0.01)$. Schooling and gender were positively associated with scorpion stings $(p=0.04)$. No deaths were registered during the 3 years of study.

According to medical reports, the main local manifestations were pain $(95 \%)$ and paresthesia $(40.3 \%, \mathrm{n}=591)$. In most of the cases $(57.5 \%, \mathrm{n}=843)$, patients received medical assistance within $1 \mathrm{~h}$ of the envenomation. The time span from the envenomation to receipt of medical assistance and to the appearance of systemic manifestations was significantly related $(p<0.01)$. Individuals who received medical assistance faster presented with systemic manifestations less frequently. The vagal syndrome (vomiting or diarrhea) was the most common systemic manifestation.

Due to the geo-processing, we were able to observe regions with different incidences of scorpion injuries (Figure 1). In order to verify possible associations between envenomation and schooling, a thematic map was built. According to data provided by the HYPERLINK "http://www.ibge.gov.br/english/" Instituto Brasileiro de Geografia e Estatística in this map, higher educational levels (high school graduates, college graduates, and undergraduates) in neighborhoods were associated with better socio-economic conditions.

On applying the kernel density technique in maps with scorpion envenomations, we observed a higher intensity of harm in the more central areas of the county. This contrasted with the finding of less-frequent registration of envenomations in the peripheral areas of the city, mainly in the Northern and Eastern regions (Figure 2).

TABLE 1

Characterization of scorpion bite cases $(n=1,466)$ assisted and registered at Ceatox-CG, Paraiba, Brazil, from 2010 to 2012 , according to socioeconomic variables.

\begin{tabular}{|c|c|c|c|c|c|}
\hline \multirow[b]{3}{*}{ Demographic and socioeconomic variables } & \multicolumn{4}{|c|}{ Gender } & \multirow{3}{*}{$\begin{array}{c}\text { p value } \\
\text { (Bicaudal) } \\
<0,01\end{array}$} \\
\hline & \multicolumn{2}{|c|}{ male } & \multicolumn{2}{|c|}{ female } & \\
\hline & n & $\%$ & n & $\%$ & \\
\hline \multicolumn{6}{|l|}{ Age groups (years) } \\
\hline $0-12$ & 139 & 9.5 & 135 & 9.2 & \\
\hline $13-28$ & 172 & 11.7 & 256 & 17.5 & \\
\hline $62-78$ & 35 & 2.4 & 92 & 6.3 & \\
\hline$\geq 79$ & 8 & 0.5 & 16 & 1.1 & \\
\hline total & 558 & 38.1 & 908 & 61.9 & \\
\hline Schooling $(n=1.449)$ & & & & & 0,04 \\
\hline no schooling & & & & 2.9 & \\
\hline complete high school & 100 & 6.9 & 181 & 12.5 & \\
\hline college under graduate & 32 & 2.2 & 55 & 3.8 & \\
\hline college graduate & 26 & 1.8 & 82 & 5.6 & \\
\hline unknown/not applying & 72 & 5.0 & 74 & 5.1 & \\
\hline total & 549 & 37.9 & 900 & 62.1 & \\
\hline Classification in the case $(n=1,466)$ & & & & & 0,25 \\
\hline low & 539 & 36.8 & 862 & 58.8 & \\
\hline moderated & 16 & 1.1 & 42 & 2.9 & \\
\hline ignored & 3 & 0.2 & 4 & 0.3 & \\
\hline total & 558 & 38.0 & 908 & 61.3 & \\
\hline
\end{tabular}

CEATOX-CG: Centro de Informação e Assistência Toxicológica de Campina Grande. Source: Data Bank of Ceatox-CG. 

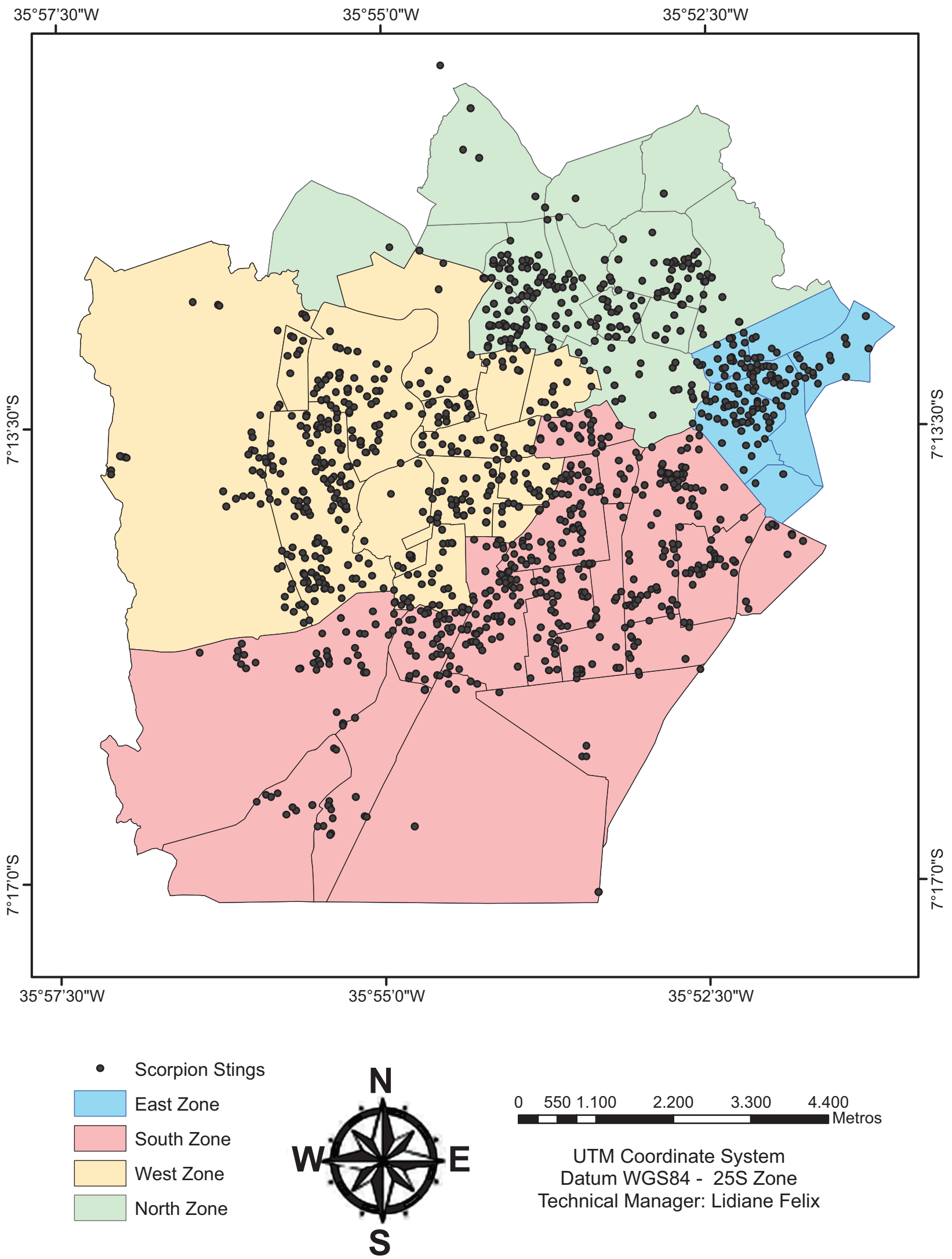

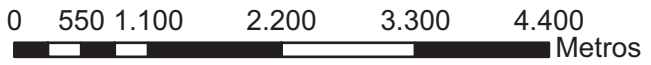

UTM Coordinate System Datum WGS84 - 25S Zone

Technical Manager: Lidiane Felix

FIGURE 1. Spatial distribution of scorpion accidents assisted and registered at Ceatox-CG, from 2010 to 2012. Ceatox-CG: Centro de Informação e Assistência Toxicológica de Campina Grande. Source: Fook, SML. 

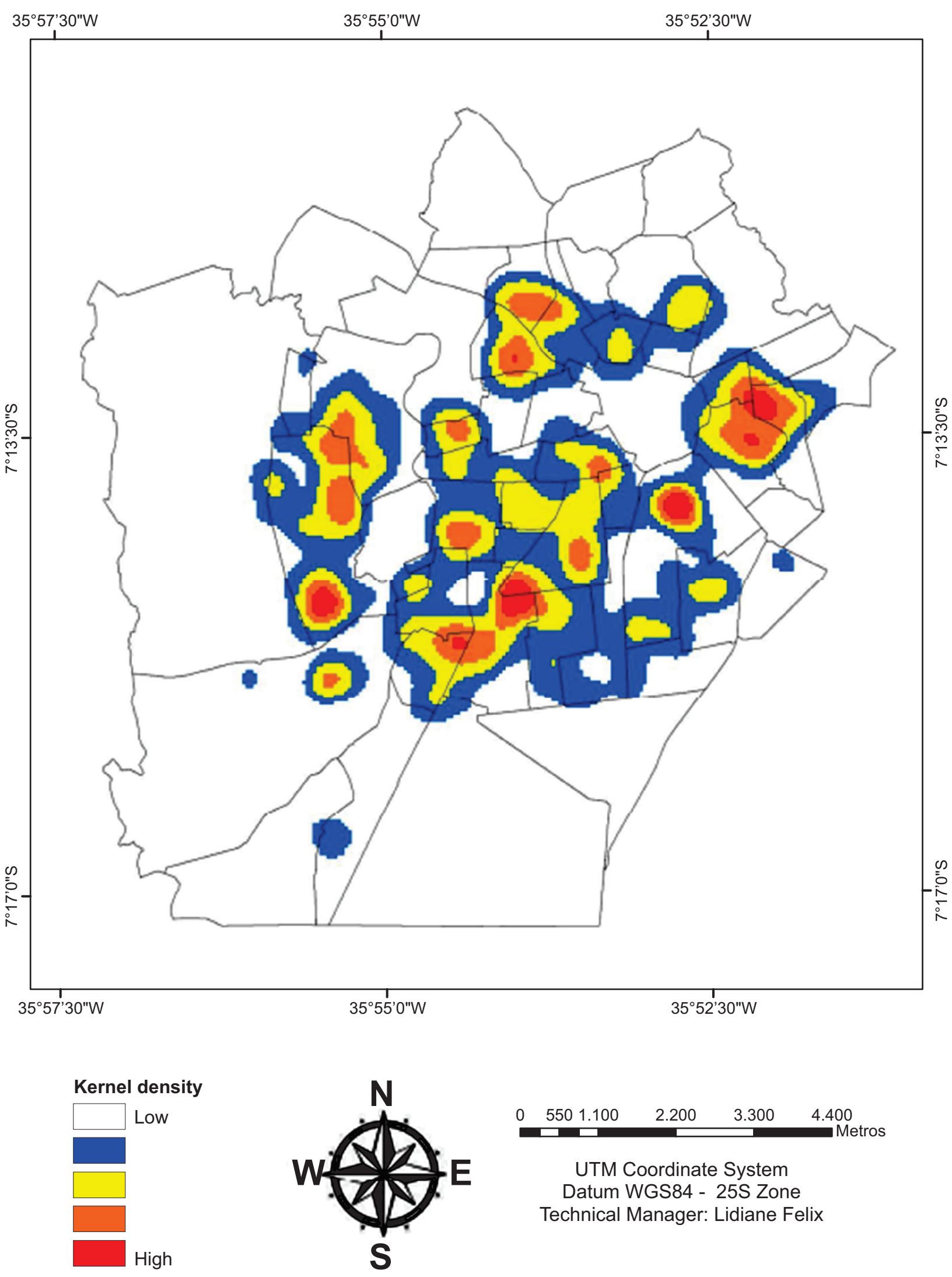

UTM Coordinate System

Datum WGS84 - 25S Zone

Technical Manager: Lidiane Felix

FIGURE 2. Density of scorpion cases assisted and registered at Ceatox-CG, from 2010 to 2012. UTM (Universal Transversa de Mercator), Ceatox-CG: Centro de Informação e Assistência Toxicológica de Campina Grande. Source: Fook, SML. 
TABLE 2

Neighborhood distribution according to occurrence zones and incidence of scorpion accidents in Campina Grande and respective family average income, from 2010 to 2012 .

\begin{tabular}{|c|c|c|c|c|}
\hline Region of occurrence & $\begin{array}{c}\text { Income value } \\
\text { nominal average monthly }\end{array}$ & $\begin{array}{c}\text { Population } \\
\text { (inhabitants) }\end{array}$ & Number & $\begin{array}{l}\text { Incidence per } \\
\text { neighborhood* }\end{array}$ \\
\hline \multicolumn{5}{|l|}{ North zone } \\
\hline Alto Branco & $1,500.00$ & 8,850 & 61 & 6,9 \\
\hline José Pinheiro & $1,000.00$ & 16,112 & 60 & 3,7 \\
\hline \multicolumn{5}{|l|}{ West zone } \\
\hline Santa Rosa & $1,020.00$ & 10,735 & 52 & 4,8 \\
\hline Malvinas & $1,020.00$ & 38,713 & 124 & 3,2 \\
\hline \multicolumn{5}{|l|}{ East zone } \\
\hline Catolé & $1,700.00$ & 19,554 & 124 & 6,34 \\
\hline JardimPaulistano & $1,700.00$ & 8,027 & 54 & 6,7 \\
\hline
\end{tabular}

*Number of incident cases per 1,000 inhabitants. Source: Demographic Censusfrom Instituto Brasileiro de Geografia e Estatística with reference to 2010.

Analysis of the frequency of injuries per region revealed that the Southern region of the city concentrated an increased number of scorpionism events $(\mathrm{n}=548)$, followed by the Western region $(\mathrm{n}=510)$. In the Eastern and Northern regions, 209 and 199 cases of scorpionism were registered, respectively. The neighborhoods of Monte Castelo (Northern region) and Bodocongó (Western region) showed higher incidence rates and were characterized by a lower average family income than neighborhoods with a lower incidence and higher average family income, such as like Alto Branco (Northern region) and Catole (Eastern region) (Table 2).

The Moran global index presented a negative spatial association for men $(-0.115 ; \mathrm{p}=0.12)$ and women $(-0.073 ; \mathrm{p}=$ 0.20 ), with a significance level above $5 \%$. This indicated that the hypothesis of contiguity between gender and specific locations of envenomations might be rejected. The value obtained from the Moran variable was compared to the average value for 50 neighborhoods in Campina Grande; the result indicated that the number of stings for both genders was not differentially related to regional area.

\section{DISCUSSION}

In the present study, victims of scorpion stings did not present severe complications or death. Compared to a previous Brazilian study, our data revealed higher incidence rates of scorpion stings ${ }^{(19)}$. In addition, a discrete gradual decrease in the incidence rate over the study duration was noted in a previous study in Belo Horizonte, State of Minas Gerais, Brazil(20).

In this study, most victims of scorpion stings were women, which is consistent with the findings of previous scientific articles from the Northeastern region of Brazil(2) (21). In contrast, other publications conducted in Brazil reported that men are more susceptible to scorpion envenomations than women ${ }^{(4)(22)(23)}$. Data from SINAN for 2013 and 2014 showed a discrete predominance of scorpion envenomations in women (approximately 53\% of the total). This increased frequency of envenomations in women in Northeastern Brazil could be due to their higher activity in the household compared to men ${ }^{(21)}$. Alternatively, women are known to obtain health care assistance, in general, more regularly than men and may more frequently seek medical help after a scorpion sting ${ }^{(24)}$. The increased frequencies of occurrences among men in certain localities may be related to their professional activities: Scorpion stings are more frequent among men who work in sawmills, wood warehouses, construction sites, potteries, quarries, and marble sites ${ }^{(23)}$.

A previous publication concluded that the Moran Index allowed identification of regions with increased spatial correlation of scorpion stings, based on the explorative analysis of vulnerability of both genders at locations of the accidents ${ }^{(25)(26)}$. However, our data about the spatial distribution of scorpion envenomation determined by the Moran Index did not indicate a self-correlation between the genders. With regard to the age group, the present study showed that the most affected group of individuals were young persons aged 13-18 years, which is consistent with the national data ${ }^{(2)(4)(27)}$. Youth of this age group are probably more vulnerability due to the increased mobility outdoor and labor activities ${ }^{(21)(28)}$ as well as the activities at home that are similar to those of women in households ${ }^{(13)}$ (21). Our results indicated that most of the patients received medical assistance within 1 hour of the scorpion sting. A shorter time span between the injury and treatment has been associated with a better prognosis for envenomation ${ }^{(28)}$. Further, 
scorpion venom may act within a few minutes following the sting $^{(29)}$,confirming that earlier treatment can reduce the severity of the envenomation. In the majority of cases in this study, no severe complications were reported. The severity of the registered envenomations depends on the scorpion species, the animal size, the quantity of injected venom, and the body mass of the victim ${ }^{(5)}$. Zoologists of the Paraíba State University in Campina Grande concluded that T. stigmurus was responsible for most cases of envenomation registered at Ceatox-CG, and although it releases venom of the highest toxicity $\left(\mathrm{LD}_{50}=\right.$ $0.773 \mathrm{mg} / \mathrm{kg}$ ) to animals, the most serious human accidents in Brazil are caused by T. serrulatus.

The maps developed by application of geo-processing techniques did not indicate a uniform distribution of scorpion stings in Campina Grande. Instead, the frequency of scorpion stings tended to concentrate in the Southern and Western regions of the county, and the Central region of the city, which was more vulnerable as compared to the suburbs. Analysis of neighborhoods with high frequencies of scorpion envenomations, showed an irregularity of case distribution: Neighborhoods that presented an average family income of more than 2 current wages, indicating better socio-economic conditions, often presented a frequency of envenomations comparable to that of neighborhoods with relatively lower average family income [close to one minimum wage (MW)]. For example, the neighborhoods of Catole and Malvinas are located in the Eastern and Western regions of the city and were characterized by an average family income of 2-3 current wages and lower than 2 current minimum wages, respectively. Most of the registered cases were concentrated in these regions together. However, a detailed analysis of the incidence of envenomations in relation to the number of inhabitants per neighborhood revealed that the neighborhood of Malvinas (Western region) has a higher population density and presented a lower incidence rate than the neighborhood of (Eastern region). The previous difference could be due to distinct population densities of scorpions in different habitats and therefore have principally a biological basis. It is well established that scorpions can disperse considerably during short time intervals due to their migratory behavior ${ }^{(19)}$. These biological factors may explain why, in the present study, socioeconomic variables were not associated with the frequency of scorpion envenomations. The results of the current study contrast those of a previous study in Minas Gerais, which showed that the highest incidence rates were noted in old and populous slum areas characterized by the lack of basic sanitation and other specific geographic aspects ${ }^{(30)}$. The populations of Campina Grande follow a standard of inequality that is also seen in other big urban centers and is characterized by living conditions that are worse in regions localized more distant to the urban center ${ }^{(31)}$.

Our study indicated that the variables studied, including income, schooling, and place of residence, did not explain the distribution of scorpionism found in Campina Grande during the study period. Moreover, there is a need to evaluate the importance of these and other variables such as climate, land, vegetation, and soil features, as they may explain the geographic distribution of envenomations in Campina Grande and other regions of Northeast Brazil. According to the literature, the incidence of scorpion envenomations predominates among populations with a low socioeconomic status. Income level, schooling, and residence location are associated with living conditions and can be measured by indicators known as Gini index and Human Development Index (HDI). It is noted that in Brazil, the Northeast presented the highest frequencies of scorpionism (48\%) and the second in number of deaths $(43.5 \%)$ almost the same (44\%) of the Southeast region. The Northeast, also, presented the highest annual average incidence of scorpionism (34.3/100,000 inhabitants) and the worst Gini index of Brazil: $0.501^{(4)}{ }^{(32)}$. Furthermore, other factors like the construction work in urban areas (with accumulation of materials like brick, wood, and clay), public and residential illumination, regular trash collection (that leads to the accumulation of cockroaches), piped water, and the sewage system impact the socioeconomic status of the population and may affect the frequency of scorpion envenomation ${ }^{(15)(23)(33)}$. Therefore, evaluation of such factors is essential for accurate determination of the causes for the progressive increase in the number of scorpion injuries registered in Brazil, particularly during the last 9 years $^{(11)}$.

The surprising increase in the annual notifications may be remarkable when bi-annual recent data from Brazil are compared; in 2007, 2009, 2011, and 2013, the number of registered envenomations was $37,339,50,383,59,200$, and 79,611 , respectively. These values indicate an average increase of 14,124 registrations every 2 years. The number of death cases in those years was $61,60,79$, and 78 , respectively. It is possible that other variables that increase the vulnerability of populations contribute to this phenomenon. In Brazil, poor infra-structure in many urban areas is characterized by problems regarding the performance of public services mentioned previously. Such infrastructure may have a meaningful role in the continuous increase of annual registrations of envenomations caused by scorpions.

One of the main challenges of controlling scorpionism is promotion of effective participation and awareness among populations. Considering that most scorpions originate at places that are located inside the house or near the house, the efficiency of control measures is a vital issue. If people have a good level of knowledge about preventive measures against scorpions, there is only poor evidence that this knowledge is put into practice ${ }^{(34)}$.

The maps and the Geographic Information System (GIS) of Campina Grande represent important instruments for surveillance and public health care. Application of mapping techniques made it possible to identify the central and northeastern regions as hot spots of scorpion stings. Further, mapping can help improve planning of public health care policy and help establish control measures such as interventions that inhibit the spread of scorpions and education campaigns about prevention of scorpion stings.

Control campaigns for scorpionism should not only be restricted to biological control, but also be integrated into environmental measures and sanitary education of communities. Thus, it is important to apply alternative tools that promote 
health education, mainly those that involve active participation of individuals in affected communities. For example, Cordel Literature is a popular source of information in Northeast Brazil and could help improve awareness about injuries caused by scorpions. In previous studies, Cordel Literature contributed successfully to health promotion and education of the populations in Northeastern Brazil ${ }^{(35)}$. Methodological and theoretical approaches, like Cordel Literature, that allow flexibility help adapt to different educational targets and are therefore pertinent to designing educational technology for health promotion.

In conclusion, in this study, geo-processing techniques allowed us to analyze the spatial distribution of scorpion envenomation in detail. As this technique can be applied to all other regions of Brazil, the present results, although restricted to Campina Grande, have national relevance. The spatial analysis provided a better view of the incidence of scorpion envenomation, indicating more injuries in the Central and Northeastern areas of the county. In these focus areas, the population was exposed to a higher risk of injuries. Furthermore, by the application of the kernel methodology and integration of data from the 2010 census, we found that the analyzed social and economic factors were not associated with the frequency of scorpion stings. According to the Moran Index, scorpion stings at defined localities were not associated with the gender.

It is important to establish training programs in exposed communities at risk that aim to establish measures for prevention and reduction of harm due to envenomations caused by scorpions. Information exchange and training of more vulnerable populations as well as health care professionals that are a part of the primary attention of health and tertiary attention are important in not only the county of Campina Grande, State of Paraíba, but all counties where envenomations with scorpions are frequent. The application of active methodologies is fundamental to decrease the incidence, morbidity, and death caused by this increasing problem of public health care in Brazil.

\section{Acknowledgments}

We offer our deepest thanks to the institutions that provided technical support for the development and implementation of this study.

\section{Conflict of interest}

The authors declare that there is no conflict of interest.

\section{REFERENCES}

1. Guerra CMN, Carvalho LFA, Colosimo EA, Freire HBM. Analysis of variables related to fatal outcomes of scorpion envenomation in children and adolescents in the state of Minas Gerais, Brazil, from 2001 to 2005. J Pediatr 2008; 84:509-515.

2. Lima ALM, Lima JA, Souto MCS, Lopes TFC, Torres UPS, Maciel ACC, et al. Spatial distribution and epidemiological profile of scorpion accidents in Natal/RN. Com Scientiae Saude 2011; 10: 627-633.

3. Malaque CMS. Estudo da ação do veneno de Tityus serrulatus sobre a expressão de transportadores de sódio e água em epitélio alveolar de rato. Tese de Doutorado. Faculdade de Medicina da Universidade de São Paulo, São Paulo, 2012.

4. Reckziegel GC, Pinto Junior VL. Scorpionism in Brazil in the years 2000 to 2012. J Venom Anim Toxins Incl Trop Dis 2014; 20:46.

5. Sistema de Informação de Agravos de Notificações (SINAN). Informações de Saúde. Acidentes por Animais Peçonhentos: Brasil. Acessado em 18 de agosto de 2016. Disponível em: http:// dtr2004.saude.gov.br/sinanweb/tabnet/dh?sinannet/animaisp/ bases/animaisbrnet.def.

6. Brazil TK, Porto, TJ. Os escorpiões. $1^{\mathrm{a}}$ edição, Salvador: Editora da Universidade Federal da Bahia (EDUFBA), 2010. p. 71-70.

7. Cupo P, Azevedo-Marques MM, Hering SE. Escorpionismo. In: Cardoso JLC, Siqueira França FO, Wen FH, Malaque CM, Haddad Jr V, editors. Animais Peçonhentos do Brasil: biologia clínica e terapêutica dos acidentes. $2^{\mathrm{a}}$ edição. São Paulo: Sarvier, 2009. p. 214-221.

8. Oliveira FN, Mortari MR, Carneiro FP, Guerrero-Vargas JA, Santos DM, Pimenta AM, et al. Another record of significant regional variation in toxicity of Tityus serrulatus venom in Brazil: a step towards understanding the possible role of sodium channel modulators. Toxicon 2013; 73:33-46.

9. Santos JM, Croesy GS, Marinho LFB. Perfil epidemiológico dos acidentes escorpiônicos em crianças, no estado da Bahia, de 2007 a 2010. Rev Enferm Contemp 2012; 1:118-129.

10. Ministério da Saúde. Manual de diagnóstico e tratamento de acidentes por animais peçonhentos (Escorpionismo). $2^{\circ}$ edição. Brasília: Fundação Nacional de Saúde. 2001. p. 37-44.

11. Sistema de Informação de Agravo de Notificações (SINAN). Informações de Saúde. Acidentes por Animais Peçonhentos: Escorpião. Paraíba. Acessado em 20 de outubro de 2015. Disponível em: http://dtr2004.saude.gov.br/sinanweb/tabnet/dh?sinannet/ animaisp/bases/animaisbrnet.def.

12. Lira-da-Silva RM, Amorim AM, Carvalho FM, Brazil TK. Acidentes por escorpião nacidade do salvador, Bahia, Brasil (19822000). Gazeta Med da Bahia 2009; 79 (supl 1):43-49.

13. Ministério da Saúde. Manual de controle de escorpiões. Brasília: 2009. 72p.

14. Chiesa AM, Westphal MF, Kashiwagi NM. Geoprocessamento e a promoção da saúde: desigualdades sociais e ambientais em São Paulo. Rev Saude Publica 2002; 36:559-567.

15. Stutz WH, Bendeck O, Macedo EM, Camargo JCC, Oliveira FS, Bonito RF, et al. Bioensaio visando controle de escorpionídeos (Tityus serrulatus), através do uso de bendiocarb, deltamethrin e lambda-cyhalothrin, 2003. Disponível em: http://www.geocities. com/HotSprings/5967/bioensaio.html. Acesso em 08 janeiro 2015.

16. Ministério da Saúde. Secretaria de Vigilância em Saúde. Fundação Oswaldo Cruz. Abordagens espaciais em saúde pública: capacitação e atualização em geoprocessamento em saúde. Brasília: Ministério da Saúde, 2006.

17. Instituto Brasileiro de Geografia e Estatística (IBGE), Censo 2010. Citado em 07 de maio de 2014. Disponível em: http://censo2010. ibge.gov.br/

18. Moran PAP. Notes on Continuous Stochastic Phenomena. Biometrika 1950; 37:17-23.

19. Kotviski BM, Barbola IF. Aspectos espaciais do escorpionismo em Ponta Grossa, Paraná, Brasil. Cad Saude Publica 2013; 29:1843-1858.

20. Barbosa AD, Magalhães DF, Silva JA, Silva MX, Cardoso MFEC, Meneses JNC, et al. Caracterização dos acidentes escorpiônicos em Belo Horizonte, Minas Gerais, Brasil, 2005 a 2009. Cad Saude Publica 2012; 28:1785-1789. 
21. Barros RM, Pasquino JA, Peixoto LR, Targino IT, de Sousa JA, Leite RS, et al. Clinical and epidemiological aspects of scorpion stings in the northeast region of Brazil. Cien Saude Colet 2014; 19:1275-1282.

22. Quadro RM, Varela AR, Cazarin MG, Marques SMT. Acidentes escorpiônicos notificados pelo SINAN na Região Serrana de Santa Catarina, Brasil, 2000-2010. Rev Eletron de Biol 2014; 7:96-108.

23. Soares MRM, Azevedo CS, De Maria M. Escorpionismo em Belo Horizonte, MG: um estudo retrospectivo. Rev Soc Bras Med Trop 2002; 35:359-363.

24. Pinheiro RS, Viacava F, Travassos C, Brito AS. Gênero, morbidade, acesso e utilização de serviços de saúde no Brasil. Cien Saude Colet 2002; 7:687-707.

25. Matos SL, Cabral APS, Siqueira MT. População vulnerável aos acidentes escorpiônicos na cidade do Recife no ano de 2010. $2^{\circ}$ Simpósio de Saúde e Ambiente. Belo Horizonte - Minas Gerais, 2014.

26. Barbosa IR, Medeiros WR, Costa ICC. Distribuição espacial dos acidentes por animais peçonhentos no Estado do Rio Grande do Norte-Brasil, no período de 2001-2010. Caminhos de Geografia Inst Geografia UFU 2015; 16:55-64.

27. Sistema Nacional de Informações Tóxico-Farmacológicas (SINITOX). Manual de Vigilância, Prevenção e Controle de Zoonoses. Normas Técnicas e Operacionais. Ministério da Saúde. Brasília: 2016. Disponível em: http://www.fiocruz.br/sinitox_novo/ media/Tabela\%2009.pdf/

28. Campolina D. Georreferenciamento e de estudo clínicoepidemiológico dos acidentes escorpiônicos atendidos em
Belo Horizonte, no serviço de Toxicologia de Minas Gerais. Dissertação de Mestrado. Belo Horizonte: 2006.

29. Freire-Maia L, Campos JA, Amaral CF. Approaches of the treatment of scorpion envenoming. Toxicon 1994; 32:1009-1014.

30. Nunes CS, Bevilacqua PD, Jardim CCG. Aspectos demográficos e espaciais dos acidentes escorpiônicos no Distrito Sanitário Noroeste, Município de Belo Horizonte, Minas Gerais, 1993 a 1996. Cad Saude Publica 2000; 16:213-223.

31. Queiroga RPF, Sá LD, Nogueira JA, Lima ERV, Silva ACO, Pinheiro PGOD, et al. Distribuição espacial da tuberculose e a relação com condições de vida no município de Campina Grande 2004 a 2007. Rev Bras Epidemiol 2012; 15:222-232.

32. Pesquisa Nacional por Amostra de Domicílios/Instituto Brasileiro de Geografia e Estatística (PNAD/IBGE), 2014. Acessado em: 18 de agosto de 2016. Disponível em: http://biblioteca.ibge.gov.br/ visualizacao/livros/liv94935.pdf

33. Barbosa AD, Silva JA, Cardoso MFEC, Meneses JNC, Cunha MCM, Haddad JPA, et al. Distribuição espacial de acidentes escorpiônicos em Belo Horizonte, Minas Gerais, 2005 a 2009. Arq Bras Med Vet Zootec 2014; 66:721-730.

34. Albuquerque CMR, Barbosa MO, Iannuzzi L. Tityus stigmurus (Thorell, 1876) (Scorpiones; Buthidae): response to chemical control and understanding of scorpionism among the population. Rev Soc Bras Med Trop 2009; 42:255-259.

35. Pagliuca LMF, Oliveira PMP, Rebouças CBA, Galvão MTG. Literatura de cordel: veículo de comunicação e educação em saúde. Texto Contexto Enferm 2007; 16:662-670. 